\title{
Relationship of Commodity and Equity Indices on Hedge Fund Performance
}

\author{
Lechner Gerhard*, Beinhauer Rupert \\ FH JOANNEUM GRAZ, University of Applied Sciences, Eggenberger Allee 11, Graz, Austria \\ *Corresponding author: gerhard.lechner@fh-joanneum.at
}

\begin{abstract}
The golden times of the hedge fund industry ended with the beginning of the financial crisis of 2007/08. Since then hedge funds have underperformed against the S\&P 500. This study shows that the Dodd Frank Act regulation was responsible for a completely changing environment for hedge funds. We have developed a model where equity indices and the CRB index are explanatory variables for hedge fund performance. Concerning methodology, data of two different phases are considered, namely the time period from 1990 to July 2010 (implementation of Dodd Frank Act) and the time period from August 2010 to April 2015. Surveys for the second time period showed that regulation was a major issue for the hedge fund industry. Especially small hedge funds find it problematic to get leverage from prime brokers and capital from investors. Another trend shown with the surveys is a general increase in the long only strategy (especially of small hedge funds). Our hypothesis assumes that the explanatory character of the MSCI Emerging Market (MSCI EM), the S\&P 500, and the CRB index for hedge fund performance is increasing in the second period. The hypothesis is found to be correct.
\end{abstract}

Keywords: hedge fund performance, hedge fund strategies, Equity Indices, Commodities, Frank Dodd Act

Cite This Article: Lechner Gerhard, and Beinhauer Rupert, "Relationship of Commodity and Equity Indices on Hedge Fund Performance.” Journal of Finance and Economics, vol. 5, no. 3 (2017): 136-144. doi: 10.12691/jfe-5-3-6.

\section{Introduction}

The main target of hedge funds is a procyclical positioning on financial markets, which means that, hedge funds should be net long risky assets in upswings on equity markets and be net short risky assets during downswing periods [1]. With that strategy the target of an Absolute Return Fund should be achieved. This does not mean that the correlations between the hedge fund returns and the risky assets should be zero because the upswing periods are very long and the downswing periods are relatively short.

There are many studies on the performance of hedge funds in comparison to other asset classes like equities $[2,3,4]$, government bonds, or corporate bonds $[5,6]$. Studies on correlations between equities and hedge fund returns show that the correlations are not stable over time but are increasing in upswing periods. So far a strong decoupling between hedge fund returns and equity returns has not been found. The studies discussed below focus on different aspects of hedge fund performance.

In bear markets, hedge funds could not perform posititively because they could not be net short in equities and other risky assets. Yet, in bull markets, hedge funds could reach an outperformance because of the high net long exposure in equities. Therefore, the question arose whether hedge funds are a good vehicle to diversify a portfolio of an institutional investor or not $[7,8]$.
The fact that hedge funds suffered from substantial losses during the great recession of 2007/08 has been documented in many papers. The total volume of all hedge funds decreased by $31 \%$ in 2008 [9] as hedge fund managers were not able to manage their illiquid portfolios [10]. [11] recently wrote a comment about the weakness of the performance of hedge funds. For him the large withdrawals of investors in July 2016 were attributable to the relative weakness of hedge funds in comparison to $\mathrm{S} \&$ P 500. He accentuaded that the correlations of hedge funds with the S \& P 500 have remained stable since the financial crisis (on a rolling 24-month basis). Brown also emphasizes that the risk-return profile of hedge funds is still better than that of other asset classes. For [11], therefore, hedge funds are still an attractive investment.

The correlations have changed over time. [4] have already shown that the advantages of portfolio optimization of hedge funds are lower than the results of a correlations analysis would give reason to expect. Yet, the correlations were much lower at the time when [4] did their analysis. A study of [12] has shown a very low correlation of hedge funds to traditional investments. Even between the different hedge fund strategies, the correlations were rather low in the 1990s.

After 2007, however, the correlations between hedge funds and traditional assets, like equities and commodities, have been rising considerably. There has also been an increase of the correlations between the different hedge fund strategies. At the same time, there was a significant weakness of the performance of hedge funds in 
comparison to the 1990's and for the first years of the new millenium [13]. A proof of weakness of the performance of hedge funds can also be found in other studies. The study by [14] on the influence of risk management on the performance of hedge funds found that the weakness of the performance can be affiliated to a non adequate risk management process of hedge funds.

[15] examined the relationship between the performance of hedge funds, the alpha and beta of the market in different phases of the business cycle. Hedge funds reduced their beta in times of macroeconomic uncertainty. Overall, Racicot/Theoret found that the procyclical development of the performance of hedge funds is decreasing over time, which indicates a learning effect in the behavior of hedge funds.

[16] examined the influence of the leverage on hedge funds. The authors found that there is a relationship between the leverage of the hedge fund and the business cycle. When interest rates are falling and the volatility of the market is decreasing (which is measured by the VIX index), the leverage of hedge funds will increase and vice versa. Generally, the leverage of hedge funds is rather low in comparison to investment banks. From the fact that the leverage of hedge funds is increasing in an upswing market, one cannot coercively conclude that there is an improving performance of hedge funds during an upswing cycle or a procyclical development of the hedge fund performance. However, the studies of [17] and [18] show a relationship between the level of the leverage and the performance of hedge funds. If there is an above-average leverage, the performance will also be above-average.

This study has two aims. Firstly, it investigates whether the correlations between equities (represented by the MSCI EM and the S\&P 500), commodities (represented by the CRB index), and the performance of hedge funds have increased after the Dodd Frank Act was put into force. Secondly, we introduce a model which provides a test module on whether the explanatory character of the variables mentioned for hedge fund performance has increased since the implementation of the Dodd Frank Act.

Our study provides a new approach to the topic. So far scientific literature has not extensively discussed the weakness of the hedge fund industry after the financial crisis, and there is no known quantitative study which has tested the findings of "Global Hedge Fund Surveys" that regulation was a major issue for the industry. Our model provides an interesting insight to the weakness of the performance of hedge funds. This model is new and has not been discussed in literature. It is an adequate tool for explaining hedge fund performance and could be interesting for investors.

As found out from the empirical analysis of the causes for weak perfomances, small funds are problematic as far as regulatory issues (e.g. higher fees) are concerned. Lower leverage opportunities (which are related to regulatory issues), indicate the need for more long only orientation. Those findings lead us to the following hypothesis tested in this paper: The explanatory power of indices (S\&P 500, MSCI EM, CRB) for the performance of hedge funds increases in the second time period (08/2010-04/2015) compared to the first time period (1990-07/2010). The second time period starts with the implementation of the Dodd Frank Act.
We found that correlations of hedge fund strategies increased significantly with regard to our three variables (with the exception of Macro Funds). The linear regressions showed that the explanation value of the indices increased in the period after the implementation of the Dodd Frank Act. Our study conveys a first useful quantitative insight into the fact that regulation was a major issue for the hedge fund industry.

\section{Causes for the Weakness of Hedge Fund Performance - Results of Surveys}

\subsection{Regulation and Leverage}

This section provides a short overview of the results of recent hedge funds surveys and the importance of leverage for the whole industry. According to surveys and other sources $[19,20,21,22]$, one cause for the weakness in the performance of the hedge funds are the increasing pressures due to regulation. Especially Basel III and the Dodd-Frank Act lead to higher fees, lower margins, increasing reporting activities and increasing compliance regulations for hedge funds. Especially, hedge funds which do not seem to be profitable for prime brokers are under pressure. Prime brokers are more restrictive in granting short-term credits and prefer large hedge funds with a solid performance, a good diversification, and a strong equity ratio. A general trend in the industry to be long only can be observed. There is a priority for smaller hedge funds with Assets under Management (AUM) below 2 billion USD to follow the long only strategy. This trend is associated with the needs and wishes of the investors who prefer long only investments of hedge funds.

Hedge funds have different channels to get a leverage. The extent of the leverage depends on the solvency and credibility of the hedge fund or on the kind of securities traded by the funds. The leverage is often provided by the prime broker in the form of short term refinancing. However, the biggest part of the leverage is provided by the margin because only a few hedge funds are on the market which are able to finance themselves on the money or on the capital market.

According to current US regulation, the maximum leverage is ruled in stock exchange trading. The Federal Reserve Board's Regulation $\mathrm{T}$ allows the investors a maximum amount of $50 \%$ above the margin (per position). There are some exceptions like interest rate swaps, treasuries, and currency swaps where the implicit leverage can rise to 100 . However, the swaps are traded "Over the counter", where the leverage could be higher than according to Regulation $T$. This information was ascertained by prime brokers and through option exchanges by [16] in March 2010. According to the authors, hedge fund managers can make offshore deals which could lead to higher leverage. Another way to increase the leverage is the portfolio margining where the margin will be charged on the whole portfolio and not per trade. This possibility was created by SEC in 2005 [16].

[18] has found that hedge funds with a higher leverage achieve a higher return. However, higher return involves a 
higher volatility of return. [20] showed that $47 \%$ of the managers with AUM of below 2 billion USD mentioned problems with aquiring capital. This is not only due to lower leverage opportunities, but also because of lower levels of interest of investors. Mainly large hedge funds have the opportunity to increase their leverage.

The data of Hedgefund Research (HFR), used in data analysis of the following section of this paper, shows the following. The hedge funds of HFR indices are equally weighted, which means that the return of small hedge funds have the same weight as the return of large hedge funds. Therefore, lower leverage opportunities for many small funds could have a relatively strong impact on the return of the whole indices. The HFR Macro funds and the Fixed Income funds are traditionally added to the funds which generate a higher leverage [22]. A study of [23] showed Relative Value strategies to have the highest leverage in the hedge fund universe. For example, Fixed Income Arbitrage is added to the Relative Value strategies. Managed Future funds have the second highest leverage and Macro funds the third highest. However, the level of the leverage of Macro funds is distorted by a very high leverage of some large funds. Many small Macro funds only have a limited leverage [23]. The Fixed Income funds for example trade the financial instruments where the margin haircut is one of the smallest [16]. The surveys also show that the impact of an increase in the fees is rather limited for the Macro funds [21].

[16] found that Relative Value strategies have the highest leverage. However, they only used four different strategies in their analysis, namely Event Driven, Relative Value, Equity, and Credit. As already mentioned, the high leverage of these strategies is achieved through the use of interest rate derivates. The cited study of Financial Authority Conduct is relatid to the gross leverage, and [22] refers to "Long Market Value/Capital-Leverage".

\subsection{Low Interest Rates on the Money Market}

A further cause of the weak performance of the hedge fund industry can be found in the low interest rates on the money markets. Cash is not popular at the moment because cash does not generate any interest in many developed markets, like the US, Japan and the Euro area. Interest rates on the money market have been nearly zero since the beginning of the financial crisis in the 2008 . Before 2008 interest rates were much higher and hedge funds were not forced to be fully invested at all times. This also plays a certain role for the performance as a whole [21].

\subsection{Increasing Information Efficiency on Financial Markets}

Apart from the causes mentioned there is, of course, the historically increasing informational market efficiency on the financial markets. [24] found that the finance industry has become more and more efficient after the information technology revolution. Since 1960, the information content of prices on financial markets has increased gradually. This increasing efficiency makes life for hedge fund managers more difficult as it is more difficult to generate alpha on the markets. This could be especially true for small long only funds. A study by [25] on the persistence of hedge fund returns showed that small hedge funds tend to have higher returns than large hedge funds because the fund managers can exploit market efficiencies more easily. [26] examined the size/return relationship with data of 1996 to 2000 and found that smaller fund outperformed larger funds. Smaller funds can benefit more easily from risk arbitrage strategies than larger funds. These studies used data which are now fifteen to twenty years old. The results of [24] indicate that the benefit of small funds could have decreased over the time because nowadays market inefficiencies are less likely than fifteen years before.

\section{Data}

\subsection{Data Selection}

As already mentioned previously, we have used the hedge fund data from Hedgefund Research (HFR). [27] and [28] have also used the HFR database. The HFR database is not the only one that can be used: [2,5,29,30,31,32], for example, used data from International Securities and Derivatives Markets (CISDM) and [15] used data of Greenwich Alternative Investment. Thus, our categorization could be compared with [27] and [28].

HFR was founded in 1994 and the data were recalculated back to 1990 for some indices. The data provider HFR was the winner of an award of HedgeWeek in 2013, 2014, and 2015. The HFRI Fund Weighted Composite Index is a total index for all hedge funds, without the Fund of Fund component. The calculation of the returns of the total Composite index is based on geometrical average of all hedge funds. Each individual hedge fund has the same weight in the Composite Index. This means that this index is not volume based. The data are in USD [33]. The data for the MSCI EM, S \& P 500 and of CRB index are from Bloomberg.

For our study we used the data of four different hedge fund strategies and two composite indices from August 1990 until April 2015. We used monthly return data.

\subsection{Data Biases}

Some biases in using hedge fund returns have to be considered [34]. The first issue is the illiquidity bias. Hedge fund managers often trade with very illiquid exchange traded or "over the counter" derivatives which causes the smoothing issue. Therefore, volatility and performance of the hedge funds are often estimated in an incorrect way. The smoothing issue could also lead to a distortion of the correlations between hedge fund returns and other asset classes.

The second bias is known as survivorship bias [35]. This bias refers to the issue of a default of a hedge fund which is part of an index. When the hedge fund is closed, the return is no longer added to the index. This sometimes leads to an overestimation of the return of the indices. This concerns especially HFR data before 1994. [36] and [37] found a bias of the annualized returns between $1.5 \%$ and 2.4\% during the periods of 1994-1998 and 1994-1999. Both authors indicate that, with regard to the survivorship 
bias, the analysis of the performance of Fund of Funds is much more efficient than that of other Hedge funds. Especially, during the crisis years of 2008/09, the survivorship bias could have been very strong. According to [9], the Assets under Management (AUM) fell by 30\% in 2008.

The third bias is called selection bias, which is based on the problem that large hedge funds are not part of certain indices because managers do not want to deliver the data. This bias has not been regarded as a big constraint because there are also hedge funds with a very strong performance which are not delivering data [38].

The fourth, and final, bias is the backfilling bias. There are often hedge funds which only later enter a certain index. The hedge fund data provider now corrects the historical data of the index. Yet, the issue is that sometimes only hedge funds with a strong performance are incorporated. This leads again to an overestimation of the whole performance of the index [35].

In addition to the four biases mentioned by [34], it has to be said that sometimes some indices are merged and also hedge funds might change the data provider [39]. As a whole, the data provider CSFB/Tremont minimizes the biases [35].

\subsection{The Problematic Nature of Correlations}

As for a correlations analysis of hedge fund returns and equity market returns, according to [39], the results of correlations between these two asset classes have to be treated with caution. Correlations with two variables are linear and therefore not resistent against outliers, which means that causal conclusions are difficult to draw. Additionally, the returns of hedge funds often show autocorrelations, which was demonstrated, for example, by [35] and [40]. According to [35], it is possible to adjust these biases through the use of quarterly data.

Hedge funds also trade with derivatives, which leads to a valuation problem because of missing market prices. Alternative pricing models have to be consulted to solve this valuation issue. However, these alternative pricing models again lead to a bias of the returns and in turn to autocorrelations [33]. Of course, these issues are touching correlations of hedge fund returns to other asset classes. The correlations tend to be overestimated because of the aforementioned issues.

\section{Empirical Results}

\subsection{Descriptive Statistic}

As already mentioned, we used two different time periods for our analysis, namely the period from August 1990 to July 2010 and from August 2010 to April 2015. With a descriptive statistic, we show that the returns of hedge funds have been considerably weakened regarding the S\&P 500 after July 2010. Furthermore, the data show the relative weakness of the CRB and the MSCI in the second time period.

Table 1 shows the monthly returns of the indices for the first time period. It can be seen that the relative performance of hedge fund strategies in comparison to S\&P 500 was very strong until July 2010. The mean of all hedge fund indices outperformed S\&P 500. The HFRI Composite Index had a higher mean than the CRB, the MSCI EM, and the S\&P 500.

The situation is different when we look at the median where only three of six indices outperformed the S\&P 500 . However, the HFRI Fund Weighted Composite Index again performed much stronger than the S\&P 500 .

An interesting result is the relative underperformance of the HFRI Relative Value Index. This contradicts the results of [18] saying that a higher leverage leads to a higher return. The underperformance of HFRI Relative Value is combined with lower volatility, which also contradicts the results of [18]. At the same time, hedge funds had a lower standard deviation than the S\&P 500 and the MSCI EM.

The highest standard deviation can be observed from the MSCI EM, which is not surprising. It can be concluded that hedge funds had a very good risk-return profile until July 2010. This was already mentioned by [2], who used data from 1996-2008.

Of course, the calculated monthly standard deviation should not be identified with volatility which is calculated by the annualized standard deviation [39,41]. The maximum of the S\&P 500 is above hedge funds and the minimum is below them. The skewness of HFRI Composite Index is lower than that of the S\&P 500 and the CRB but higher than the skewness of the MSCI EM.

Table 1. Descriptives 1990-07/2010

\begin{tabular}{|l|c|c|c|c|c|c|c|}
\hline & Mean & Median & Std. Deviation & Skewness & Kurtosis & Minimum & Maximum \\
\hline MSCI EM & 1,02 & 1,30 & 6,49 & $-0,75$ & 1,84 & $-29,29$ & 16,45 \\
\hline S\&P500 & 0,78 & 1,05 & 3,93 & $-0,47$ & 1,01 & $-14,58$ & 11,16 \\
\hline CRB & 0,24 & 0,28 & 2,05 & $-0,51$ & 1,79 & $-8,16$ & 5,63 \\
\hline HFRI Equity Hedge (Total) Index & 1,31 & 1,35 & 2,46 & 0,19 & 1,55 & $-7,65$ & 10,88 \\
\hline HFRI Event-Driven (Total) Index & 1,12 & 1,34 & 1,84 & $-1,25$ & 4,63 & $-8,90$ & 5,13 \\
\hline HFRI Fund of Funds Composite Index & 0,81 & 0,81 & 1,58 & $-0,28$ & 4,05 & $-7,47$ & 6,85 \\
\hline HFRI Fund Weighted Composite Index & 1,10 & 1,32 & 1,91 & $-0,59$ & 2,94 & $-8,70$ & 7,65 \\
\hline HFRI Macro (Total) Index & 1,20 & 0,85 & 2,30 & 0,39 & 0,78 & $-6,40$ & 7,88 \\
\hline HFRI Relative Value (Total) Index & 0,94 & 0,92 & 1,01 & $-0,80$ & 10,43 & $-5,80$ & 5,72 \\
\hline
\end{tabular}

Note: all figures are based on monthly returns 
Table 2. Descriptives 08/2010-04/2015

\begin{tabular}{|l|c|c|c|c|c|c|c|}
\hline & Mean & Median & Std. Deviation & Skewness & Kurtosis & Minimum & Maximum \\
\hline MSCI EM & 0,07 & 0,04 & 7,19 & $-0,54$ & 2,02 & $-27,50$ & 16,66 \\
\hline S\&P500 & 0,52 & 1,16 & 4,80 & $-0,80$ & 1,35 & $-16,94$ & 10,77 \\
\hline CRB & 0,07 & $-0,05$ & 3,66 & $-0,97$ & 4,26 & $-14,45$ & 8,57 \\
\hline HFRI Equity Hedge (Total) Index & 0,24 & 0,44 & 2,72 & $-0,88$ & 1,90 & $-9,46$ & 6,37 \\
\hline HFRI Event-Driven (Total) Index & 0,36 & 0,53 & 2,02 & $-1,33$ & 3,67 & $-8,19$ & 4,74 \\
\hline HFRI Fund of Funds Composite Index & 0,08 & 0,38 & 1,63 & $-1,62$ & 4,30 & $-6,54$ & 3,32 \\
\hline HFRI Fund Weighted Composite Index & 0,27 & 0,41 & 1,93 & $-0,94$ & 2,45 & $-6,84$ & 5,15 \\
\hline HFRI Macro (Total) Index & 0,23 & 0,02 & 1,37 & 0,45 & 0,03 & $-2,62$ & 4,22 \\
\hline HFRI Relative Value (Total) Index & 0,44 & 0,61 & 1,61 & $-2,42$ & 10,50 & $-8,03$ & 3,93 \\
\hline
\end{tabular}

Note: all figures are based on monthly returns

Table 2 shows the monthly returns of the indices for the second time period. It is noticeable that the mean of the hedge funds is much lower than compared with the mean of the first time period. All hedge fund strategies underperformed the S\&P 500 in the second time period.

The best hedge fund strategy is represented by Relative Value. The performance of the MSCI EM, the Fund of Fund Composite, and the CRB index was very weak. Yet, no hedge fund indices underperformed the MSCI EM.

Concerning the standard deviation, hedge funds remain better than the S \& P 500 and the MSCI EM. The CRB index had the lowest mean and median of all indices during the second time period. A strong decrease in the standard deviation in comparison to the first period can be observed from the Macro strategies.

[18] arguments that a higher leverage leads to a higher return and a higher standard deviation is partially supported by the data. For example, the Relative Value strategy outperforms the HFRI Composite index from the mean value perspective, but the standard deviation is lower, which again contradicts the findings of Tolonen. The results are also not in line with the results of [14], who claim that a weaker risk management is responsible for the weakness of the performance of hedge funds.

The MSCI EM has again the highest standard deviation. For the second period, the CRB index showed a strong increase in the standard deviation in comparison to the first time period. With the exception of Macro Funds, the skewness of hedge fund indices is lower than in the first time period.

\subsection{Correlations}

Table 3 and Table 4 show the correlations of the hedge fund indices with our three variables in the two time periods. The correlations with the S\&P 500 index have increased in the second time period with only one exception, namely the Macro Total.

The correlations in the first time period are near zero and, therefore, not significant, while, in the second time period, the correlations are all significant. In the second time period, all hedge fund strategies show a significant and high increase in the correlations. The increase of the correlations of hedge fund indices is much stronger with the CRB index. The correlations with the S\&P 500 and the MSCI EM are extremely high. Even the correlation between the Fund of Funds Composite and our variables is very high in the second time period, and the increase in the HFRI Relative Value Index stands out especially.

\subsection{Regression for the Selected Variables}

The next step is to find the relative importance of our variables in explaining the return of the hedge fund strategies. Our linear regression model should be able to explain the relative importance of our independent variables in the different time periods.

Our basic hypothesis derived from the correlation analysis is that the explanation value of the independent variables should have increased significantly in the second period. Our basic performance measurement model is illustrated in Equation 1:

$$
\begin{aligned}
\mathrm{Y}_{\mathrm{t}}= & \mathrm{B}_{\mathrm{MSCI} E M} * \mathrm{X}_{1 \mathrm{t}}+\mathrm{B}_{\mathrm{S} \& \mathrm{P} 500} * \mathrm{X}_{2 \mathrm{t}} \\
& +\mathrm{B}_{\mathrm{CRB}} * \mathrm{X}_{3 \mathrm{t}}+\text { Const }+\varepsilon
\end{aligned}
$$

$Y_{t}$ represents the return of the hedge fund indices. The betas of the model show the relative explanation value of the individual explanatory variable.

Table 5 shows the dependent variable HFRI Fund of Funds Composite Index. The regression of the HFRI Fund of Funds Composite Index shows a strong increase of the beta of the CRB index in the second time period. In the first time period, however, the CRB was not significant. The same is true for the S\&P 500, which was also not significant in the first time period. The beta of the MSCI Emerging Market remained significantly high in the second time period. Another important and logical result is the strong increase in the adjusted $\mathrm{R}$ square in the second time period. The adjusted $\mathrm{R}$ square rose from 0.37 to 0.66 . The Durbin-Watson test showed that there are no first order autocorrelations. We found no collinearity either.

Table 6 presents the results for the dependent variable HFRI Fund Weighted Composite Index. In the first time period, the MSCI EM and the S\&P 500 are highly significant but the CRB index is not significant. In the second time period, all variables are highly significant and the adjusted $\mathrm{R}$ square has increased significantly from 0.65 to 0.86 . The beta of the MSCI EM remained high in the second time period. The Durbin-Watson test showed no autocorrelations, and we found no collinearity either. 
Table 3. Correlations 1990-07/2010

\begin{tabular}{|c|c|c|c|c|c|}
\cline { 2 - 6 } \multicolumn{1}{c|}{} & $\begin{array}{c}\text { HFRI Equity } \\
\text { Hedge (Total) } \\
\text { Index }\end{array}$ & $\begin{array}{c}\text { HFRI Event- } \\
\text { Driven (Total) } \\
\text { Index }\end{array}$ & $\begin{array}{c}\text { HFRI Fund of } \\
\text { Funds Composite } \\
\text { Index }\end{array}$ & $\begin{array}{c}\text { HFRI Fund } \\
\text { Weighted } \\
\text { Composite Index }\end{array}$ & $\begin{array}{c}\text { HFRI Macro } \\
\text { (Total) Index }\end{array}$ \\
\hline MSCI EM &, $63^{* *}$ &, $61^{* *}$ &, $59^{* *}$ &, $49^{* *}$ \\
\hline S\&P500 &, $67^{* *}$ &, $60^{* *}$ &, $41^{* *}$ &, $39^{* *}$ \\
\hline CRB & $-0,01$ & 0,02 & 0,00 & 0,01 &, $36^{* *}$ \\
\hline
\end{tabular}

Table 4. Correlations 08/2010-04/2015

\begin{tabular}{|c|c|c|c|c|c|}
\hline & $\begin{array}{c}\text { HFRI Equity } \\
\text { Hedge (Total) } \\
\text { Index }\end{array}$ & $\begin{array}{c}\text { HFRI Event- } \\
\text { Driven (Total) } \\
\text { Index }\end{array}$ & $\begin{array}{c}\text { HFRI Fund of } \\
\text { Funds Composite } \\
\text { Index }\end{array}$ & $\begin{array}{c}\text { HFRI Fund } \\
\text { Weighted } \\
\text { Composite Index }\end{array}$ & $\begin{array}{c}\text { HFRI Macro } \\
\text { (Total) Index }\end{array}$ \\
\hline MSCI EM &, $86^{* *}$ &, $74^{* *}$ &, $71^{* *}$ &, $36^{* *}$ \\
\hline S\&P500 &, $88^{* *}$ &, $81^{* *}$ &, $75^{* *}$ &, $69^{* *}$ \\
\hline CRB &, $42^{* *}$ &, $51^{* *}$ &, $44^{* *}$ &, $47^{* *}$ &, $28^{* *}$ \\
\hline
\end{tabular}

Table 5. HFRI Fund of Funds Composite Indexa

\begin{tabular}{|c|c|c|c|c|c|c|}
\hline \multirow{2}{*}{\multicolumn{2}{|c|}{ Part of the Dataset }} & \multicolumn{2}{|c|}{ Unstandardized Coefficients } & \multirow{2}{*}{$\frac{\text { Standardized Coefficients }}{\text { Beta }}$} & \multirow{2}{*}{$\mathrm{t}$} & \multirow{2}{*}{ Sig. } \\
\hline & & B & Std. Error & & & \\
\hline \multirow{4}{*}{$1990-07 / 2010$} & (Constant) & 0,65 & 0,09 & & 7,37 & 0,00 \\
\hline & MSCI EM & 0,14 & 0,02 & 0,55 & 7,93 & 0,00 \\
\hline & S\&P500 & 0,04 & 0,03 & 0,09 & 1,36 & 0,18 \\
\hline & CRB & $-0,02$ & 0,04 & $-0,02$ & $-0,44$ & 0,66 \\
\hline \multirow{4}{*}{ 07/2010-08/2015 } & (Constant) & 0,02 & 0,10 & & 0,15 & 0,88 \\
\hline & MSCI EM & 0,10 & 0,03 & 0,43 & 3,72 & 0,00 \\
\hline & S\&P500 & 0,10 & 0,04 & 0,29 & 2,62 & 0,01 \\
\hline & CRB & 0,10 & 0,03 & 0,23 & 3,24 & 0,00 \\
\hline
\end{tabular}

a. Dependent Variable: HFRI Fund of Funds Composite Index

Table 6. Coefficients HFRI Fund Weighted Composite Index ${ }^{a}$

\begin{tabular}{|c|c|c|c|c|c|c|}
\hline \multirow{2}{*}{\multicolumn{2}{|c|}{ Part of the Dataset }} & \multicolumn{2}{|c|}{ Unstandardized Coefficients } & \multirow{2}{*}{$\begin{array}{c}\text { Standardized Coefficients } \\
\text { Beta }\end{array}$} & \multirow{2}{*}{$\mathrm{t}$} & \multirow{2}{*}{ Sig. } \\
\hline & & B & Std. Error & & & \\
\hline \multirow{4}{*}{$1990-07 / 2010$} & (Constant) & 0,82 & 0,08 & & 10,46 & 0,00 \\
\hline & MSCI EM & 0,16 & 0,02 & 0,53 & 10,22 & 0,00 \\
\hline & S\&P500 & 0,18 & 0,03 & 0,36 & 6,95 & 0,00 \\
\hline & $\mathrm{CRB}$ & $-0,01$ & 0,04 & $-0,01$ & $-0,28$ & 0,78 \\
\hline \multirow{4}{*}{ 07/2010-08/2015 } & (Constant) & 0,19 & 0,08 & & 2,48 & 0,02 \\
\hline & MSCI EM & 0,15 & 0,02 & 0,55 & 7,54 & 0,00 \\
\hline & S\&P500 & 0,12 & 0,03 & 0,31 & 4,42 & 0,00 \\
\hline & CRB & 0,10 & 0,02 & 0,18 & 3,97 & 0,00 \\
\hline
\end{tabular}

a. Dependent Variable: HFRI Fund Weighted Composite Index.

Table 7. Coefficients HFRI Equity Hedge (Total) Index ${ }^{a}$

\begin{tabular}{|c|c|c|c|c|c|c|}
\hline \multirow{2}{*}{\multicolumn{2}{|c|}{ Part of the Dataset }} & \multicolumn{2}{|c|}{ Unstandardized Coefficients } & \multirow{3}{*}{$\begin{array}{c}\text { Standardized Coefficients } \\
\text { Beta }\end{array}$} & \multirow{3}{*}{$\begin{array}{c}\mathrm{t} \\
8,15\end{array}$} & \multirow{3}{*}{$\begin{array}{l}\text { Sig. } \\
0,00\end{array}$} \\
\hline & & \multirow{2}{*}{$\frac{\mathrm{B}}{0,99}$} & \multirow{2}{*}{$\begin{array}{c}\text { Std. Error } \\
0,12\end{array}$} & & & \\
\hline \multirow{4}{*}{$1990-07 / 2010$} & (Constant) & & & & & \\
\hline & MSCI EM & 0,13 & 0,02 & 0,34 & 5,44 & 0,00 \\
\hline & S\&P500 & 0,27 & 0,04 & 0,44 & 7,02 & 0,00 \\
\hline & CRB & $-0,03$ & 0,06 & $-0,03$ & $-0,53$ & 0,60 \\
\hline \multirow{4}{*}{ 07/2010-08/2015 } & (Constant) & 0,11 & 0,10 & & 1,16 & 0,25 \\
\hline & MSCI EM & 0,21 & 0,02 & 0,55 & 8,44 & 0,00 \\
\hline & S\&P500 & 0,22 & 0,04 & 0,39 & 6,23 & 0,00 \\
\hline & CRB & 0,08 & 0,03 & 0,10 & 2,54 & 0,01 \\
\hline
\end{tabular}

a. Dependent Variable: HFRI Equity Hedge (Total) Index. 
Table 8. Coefficients HFRI Event-Driven (Total) Index ${ }^{\mathrm{a}}$

\begin{tabular}{|c|c|c|c|c|c|c|}
\hline \multirow{2}{*}{\multicolumn{2}{|c|}{ Part of the Dataset }} & \multicolumn{2}{|c|}{ Unstandardized Coefficients } & \multirow{2}{*}{$\begin{array}{c}\text { Standardized Coefficients } \\
\text { Beta } \\
\end{array}$} & \multirow{2}{*}{$\mathrm{t}$} & \multirow{2}{*}{ Sig. } \\
\hline & & B & Std. Error & & & \\
\hline \multirow{4}{*}{$1990-07 / 2010$} & (Constant) & 0,90 & 0,09 & & 10,26 & 0,00 \\
\hline & MSCI EM & 0,12 & 0,02 & 0,42 & 6,79 & 0,00 \\
\hline & S\&P500 & 0,17 & 0,03 & 0,37 & 5,95 & 0,00 \\
\hline & CRB & 0,03 & 0,04 & 0,03 & 0,60 & 0,55 \\
\hline \multirow{4}{*}{$2010-08 / 2015$} & (Constant) & 0,25 & 0,10 & & 2,64 & 0,01 \\
\hline & MSCI EM & 0,10 & 0,02 & 0,34 & 3,97 & 0,00 \\
\hline & S\&P500 & 0,18 & 0,03 & 0,43 & 5,25 & 0,00 \\
\hline & CRB & 0,15 & 0,03 & 0,27 & 5,07 & 0,00 \\
\hline
\end{tabular}

a. Dependent Variable: HFRI Event-Driven (Total) Index.

Table 9. Coefficients HFRI Macro (Total) Index ${ }^{a}$

\begin{tabular}{|c|c|c|c|c|c|c|}
\hline \multirow{2}{*}{\multicolumn{2}{|c|}{ Part of the Dataset }} & \multicolumn{2}{|c|}{ Unstandardized Coefficients } & \multirow{3}{*}{$\begin{array}{c}\text { Standardized Coefficients } \\
\text { Beta }\end{array}$} & \multirow{3}{*}{$\frac{t}{7,24}$} & \multirow{3}{*}{$\begin{array}{l}\text { Sig. } \\
0,00\end{array}$} \\
\hline & & \multirow{2}{*}{$\frac{\mathrm{B}}{1,02}$} & \multirow{2}{*}{$\begin{array}{c}\text { Std. Error } \\
0,14\end{array}$} & & & \\
\hline \multirow{4}{*}{$1990-07 / 2010$} & (Constant) & & & & & \\
\hline & MSCI EM & 0,15 & 0,03 & 0,41 & 5,33 & 0,00 \\
\hline & S\&P500 & 0,07 & 0,05 & 0,12 & 1,55 & 0,12 \\
\hline & CRB & $-0,06$ & 0,07 & $-0,06$ & $-0,94$ & 0,35 \\
\hline \multirow{4}{*}{ 07/2010-08/2015 } & (Constant) & 0,25 & 0,14 & & 1,76 & 0,08 \\
\hline & MSCI EM & 0,07 & 0,04 & 0,38 & 2,02 & 0,05 \\
\hline & S\&P500 & $-0,05$ & 0,05 & $-0,19$ & $-1,06$ & 0,29 \\
\hline & CRB & 0,05 & 0,04 & 0,13 & 1,13 & 0,26 \\
\hline
\end{tabular}

a. Dependent Variable: HFRI Macro (Total) Index.

Table 10. HFRI Relative Value (Total) Index ${ }^{a}$

\begin{tabular}{|c|c|c|c|c|c|c|}
\hline \multirow{2}{*}{\multicolumn{2}{|c|}{ Part of the Dataset }} & \multicolumn{2}{|c|}{ Unstandardized Coefficients } & \multirow{3}{*}{$\begin{array}{c}\text { Standardized Coefficients } \\
\text { Beta } \\
\end{array}$} & \multirow{3}{*}{$\frac{t}{13,24}$} & \multirow{3}{*}{$\begin{array}{l}\text { Sig. } \\
0,00\end{array}$} \\
\hline & & \multirow{2}{*}{$\frac{\mathrm{B}}{0,85}$} & \multirow{2}{*}{$\begin{array}{c}\text { Std. Error } \\
0,06\end{array}$} & & & \\
\hline \multirow{4}{*}{$1990-07 / 2010$} & (Constant) & & & & & \\
\hline & MSCI EM & 0,05 & 0,01 & 0,30 & 3,70 & 0,00 \\
\hline & S\&P500 & 0,04 & 0,02 & 0,17 & 2,15 & 0,03 \\
\hline & CRB & 0,04 & 0,03 & 0,08 & 1,34 & 0,18 \\
\hline \multirow{4}{*}{ 2010-08/2015 } & (Constant) & 0,40 & 0,09 & & 4,39 & 0,00 \\
\hline & MSCI EM & 0,11 & 0,02 & 0,48 & 4,71 & 0,00 \\
\hline & S\&P500 & 0,05 & 0,03 & 0,16 & 1,58 & 0,12 \\
\hline & CRB & 0,16 & 0,03 & 0,36 & 5,64 & 0,00 \\
\hline
\end{tabular}

a. Dependent Variable: HFRI Relative Value (Total) Index.

Table 7 presents the results for dependent variable HFRI Equity Hedge Index. The results are similar to those for the variable HFRI Fund Weighted Composite Index discussed above. The significance of the CRB index improved significantly in the second time period. The adjusted $\mathrm{R}$ square rose from 0.49 to 0.89 . The Durbin-Watson test showed no autocorrelations, and we found no collinearity either.

Table 8 shows the dependent variable HFTI Event-Driven Index. The results are very similar to the Equity Hedge Index. For the HFTI Event-Driven Index, all variables are highly significant in the second time period. In the first time period, the CRB index was not significant. The $\mathrm{R}$ square improved from 0.50 to 0.81 . We neither found an autocorrelation nor a collinearity.

Table 9 shows the dependent variable HFRI Macro Index. It turns out that only the HFRI Macro Index cannot be explained with our model. The R square fell from 0.23 to 0.08 , and the S\&P 500 and the CRB index are not significant in the second time period.

As Table 10 shows, the HFRI Relative Value Index as a variable indicates very interesting results. The $\mathrm{R}$ square rose from 0.18 to 0.73 . In the second time period, the S\&P 500 was not significant. Yet, especially the CRB index is very significant. We found no autocorrelation and no collinearity.

\section{Conclusions}

The aim of the paper was to find the relationship of equity and commodity indices for hedge fund performance before and after the implementation of the Dodd Frank Act in 2010. There is an increasing importance of the long 
only strategy mainly due not only to regulation issues, but also to investors favoring this strategy. Regulatory issues impact especially small hedge funds because small hedge funds are, for example, not able to get leverage as easily as before the financial crisis. The prime brokers are more restrictive and prefer hedge funds with a solid solvency and credibility. Concerning the methods of charging the indices, there is no difference in the weights of small and large hedge funds. All funds are equally weighted. Our hypothesis was that the explanatory power of our three indices for the hedge fund performance would increase. We tested the hypothesis with a regression model.

Our data analysis of the period until July 2010 and the period after supported our hypothesis. We found that the correlations increased significantly for all independent variables (with the exception of Macro Funds). For the CRB index, we could observe the strongest increase in the correlations (including Macro strategies). Concerning the MSCI EM, we found similar results to the results of S\&P 500. Our regression analysis proved that our explaining variables became significantly more important in the second time period. Especially the explanatory power of the CRB index increased significantly. Until the implementation of the Dodd FrankAct, the CRB index was not significant in our model. The adjusted $\mathrm{R}$ square also rose significantly (with the exception of Macro Funds). The strongest increase in the $\mathrm{R}$ square can be found in the Relative Value index which traditionally had a high leverage. In the case of the Relative Value index, regulation and more long only positions seem to have a considerable effect on the performance.

Our paper is the first quantitative investigation of the weakness of hedge funds performance since the introduction of the Frank Dodd Act. The increasing relationship between our selected variables and hedge fund performance is a first indication why hedge fund performance has weakened. Further research has to be done to explain why the Macro Funds behaved differently.

\section{Acknowledgements}

We are grateful to Roland Mestel for helpful suggestions and comments that significantly improved the quality of this research.

\section{References}

[1] Lechner, G. 2016. "The behavior of hedge funds and the theory of the business cycle”, Journal of US-china public administration, pp. $1-15$.

[2] Elling, M., Faust, R. 2010. "The performance of hedge funds and mutual funds in emerging markets", Journal of Banking \& Finance, 34, 1993-2009.

[3] Banz, R., Planta de R. 2002. "Hedge Funds: All that glitters is not gold - Seven Questions for prospective Investors”, Financial Markets and Portfolio Management, 16 (3), 316-336.

[4] Füss, R., Kaiser, D. 2007. "The tactical and strategical value of hedge fund strategies: A cointegration approach”, Financial Markets and Portfolio Management, 21 (4), 425-444.

[5] Capocci, D. Hübner, G. 2004. "Analysis of hedge fund performance”, Journal of Empirical Finance, 11 (1), 55-89.

[6] Do, V., Faff, R., Wickramanayake, J. 2005. "The empirical analysis of hedge fund performance: Australian hedge fund industry”, Journal of Multinational Financial Management, 15 (4-5), 377-393.

[7] Sandvik, S. H., Frydenberg, S., Westgaard, S., Heitmann, R. K. 2011. "Hedge fund performance in bull and bear markets: alpha creation and risk exposure”, Journal of Investing, 20 (1), 52-77.

[8] Ennis, R. M., Sebastian, M. D. 2003. "A critical look at the case for hedge fund”, Journal of Portfolio Management, 29 (4), 103-112.

[9] Statista. 2016. „Verwaltetes Vermögen von Hedgefonds“, https://de.statista.com/statistik/daten/studie/37167/umfrage/verwal tetes-vermoegen-in-hedgefonds-weltweit-seit-2000/ (Retrieved on 26 September 2016).

[10] Schaub, N., Schmid, M. 2013. "Hedge fund liquidity and performance: Evidence from financial crisis”, Journal of Banking and Finance, 37 (3), 671-692.

[11] Brown, S. J. 2016. “Why hedge funds?” Financial Analyst Journal, 72 (6), 5-7.

[12] Liang, B. 1999. “On the performance of hedge funds”, Financial Analyst Journal, 55 (4), 72-85.

[13] Atilgan, Y., Bali, T.G., Demirtas, K.O. 2013. "The performance of hedge fund indices” Borsa Istanbul Review, 13 (3), 30-52.

[14] El Karak, I. Azevedo, A., Hudson, R. 2016. "Reviewing the hedge funds literature II: Hedge Fund Returns and Risk Management characteristics”, International Review of Financial Analysis, 48, 55-66.

[15] Racicot, F.E., Theoret, R. 2016. "Macroeconomic shocks, forward looking dynamics, and the behaviour of hedge funds", Journal of Banking and Finance, 62, 41-61.

[16] Ang, A., Gorovyy, S., and van Inwegen, G. B. 2011. "Hedge fund leverage", Journal of Financial Economics, 102, 102-126.

[17] Schneeweis, T. Kazemi, H., Martin, G. 2002. "Understanding hedge fund performance: research issues revisited- Part I”, Journal of Alternative Investments, 5 (3), 6-22.

[18] Tolonen, P. "Three essay on hedge fund performance" Dissertation, University of Oulu, 2014.

[19] Global Hedge Fund and Investor Survey. 2013. "Global hedge fund survey 2013”, http://www.ey.com/Publication/vwLUAssets/EY__2013_global_hedge_fund_and_investor_survey/\$FILE/EYHedge-fund-survey.pdf. Retrieved on 17 October 2016.

[20] Global Hedge Fund and Investor Survey. 2014. "Global hedge fund survey 2014", http://www.ey.com/Publication/vwLUAssets/2014_Global_Hedge _Fund_and_Investor_Survey/\$FILE/2014\%20Global\%20-Hedge\% 20Fund\%20and\%20Investor\%20Survey.pdf, Retrieved from: 17 October 2016.

[21] Global Hedge Fund and Investor Survey. 2015. Global hedge fund survey 2015. http://www.ey.com/Publication/vwLUAssets/ey-2015-globalhedge-fund-and-investor-survey/\$FILE/ey-2015-global-hedgefund-and-investor-survey.pdf. Retrieved from: 17 October 2016.

[22] Barbarino, F. (2009). "Leverage, hedge funds and risk" NEPC Research, 3,

http://www.nepc.com/writable/research_articles/file/09_07_nepc_l everage_hf_and_risk.pdf. Retrieved on 17 October 2016.

[23] Financial Authority Contact. 2015. "Hedge Fund Survey June 2015”,

https://www.fca.org.uk/publication/data/hedge-fund-survey.pdf, (Retrieved on 24 October 2016).

[24] Bai, J., Phillippon, T., Savov, A. 2016. "Have financial markets become more informative”, Journal of Financial Economics, 112 (3), 625-654.

[25] Harri, A., Browsen, B. 2004. "Performance persistence and the source of returns for hedge funds”, Applied Financial Economics, 14 (2), 131-141.

[26] Schneeweis, T., Martin, G., Kazemi, H., Karavas, V. 2005. "The impact of leverage on Hedge fund risk and return”, Journal of Alternative Investments, 7 (4), 10-21.

[27] Abugri, B.A., Dutta., S., 2009. "Emerging markets hedge funds: Do they perform like regular hedge funds?”, Journal of Financial Markets, Institutions \& Money, 19 (5), 834-849.

[28] Aiken, A. L., Kilic, O., Reid, S. 2016. "Can hedge funds time global equity markets. Evidence from emerging markets”, Review of Financial Economics, 29, 2-11.

[29] Edwards, F., Caglayan, M. 2001. "Hedge fund performance and manager skill”, Journal of Futures Markets, 21 (11), 1003-1028. 
[30] Kouwenberg, R. 2003. "Do Hedge Funds add value to a passive portfolio? Correcting for non-normal returns and disappearing funds”, Journal of Asset Management, 3 (4), 361-382.

[31] Ding, B. Shawky, H.A. 2007. The performance of hedge funds strategies and the asymmetry of return distributions. European Financial Management. 13 (2). pp. 309-331.

[32] Chen, L.-W., Chen, F. 2009. "Does concurrent management of mutual and hedge funds create conflicts of interest?”, Journal of Banking and Finance, 33 (8), 1423-1433.

[33] Kaiser, D. „Hedgefonds - Entmystifizierung einer Assetklasse“, 1. Edition, GWV Fachverlage GmbH, Wiesbaden, 2004.

[34] Albrecht, P., Mandl, J. 2005. "Hedgefonds in der Kapitalanlage von Versicherungsunternehmen. Caveats aus wissenschaftlicher Sicht“, Working Paper, Mannheimer Manuskripte zur Risikotheorie und Portfoliomanagement und Versicherungswirtschaft, https://ub-madoc.bib.uni-mannheim.de/1248/ (Retrieved on 29 September 2016)
[35] Asness, C., Krail, R., Liew, J. 2001. “Do Hedge Funds Hedge?” Journal of Portfolio Management, 27 (3), 6-19.

[36] Fung, W., Hsieh, D. A. 2000. "Performance characteristica of Hedge Funds and Commodity Funds: Natural vs. Spurious Biases”, Journal of Financial and Quantitative Analysis, 35, 291-308.

[37] Liang, B. 2001. "Hedge Fund Performance: 1990-1999”, Financial Analyst Journal, 57 (1), 11-18.

[38] Fung, W., Hsieh, D. A. 1997. „Empirical characteristics of dynamic trading strategies: The case of hedge funds”, Review of Financial Studies, 10 (2), 275-302.

[39] Lhabitant, F. S. "Hedge Funds - Quantitative Insights", John Wiley \& Sons Limited, Chichester, 2004.

[40] Kat, H.M., Lu, S., "Some statistical properties of hedge funds returns” In: Dichtl, H., Kleeberg, J. M., Schlenger, C. (ed). Handbuch Hedge Funds. Uhlenbruch, Bad Soden, 2005, pp. 197-210.

[41] Kaiser, D. „Hedgefonds - Entmystifizierung einer Assetklasse“ 2. Edition. Wiesbaden: GWV Fachverlage GmbH, Wiesbaden, 2009. 